\title{
GENDER GAPS IN VOTER'S BEHAVIOUR IN MODERN UKRAINE: FACTORS AND INFLUENCE
}

\author{
Nataliia Dziuba \\ Department of youth work \\ State Institution "State Institute for Family and Youth Policy" \\ 18 Isaakyan str., Kyiv, Ukraine, 01135 \\ Department of Sociology and Social Work \\ Classical private university \\ $70 b$ Zhukovskogo str., Zaporizhzhia, Ukraine, 69002
}

\begin{abstract}
The article deals with the important and insufficiently studied problem of specificity of the gender influence on electors' orientations in modern Ukraine. The studies fixed the presence of gender gaps in the electoral behavior - certain difference in electoral activity (participation in elections) and electoral preferences (decision about whom to give the own voice) among men and women.

Based on the analysis of the situation in the Ukrainian society, there was determined, that the real gender gap in the electoral behavior of women and men is conditioned by the series of factors: historical (1), ideological (2), economic (3), social (4), political (5), cognitive-propagandist (6), stereotype and others (7).Their influence really determines a motivation of making electoral decisions by them. It was established, that just these factors, added by the series of partial ones (regional, type and level of elections, strategies of organizing election campaigns and so on) determine the presence of differences in the electoral behavior of men and women.

Present gender gaps testify not only to the difference in the attitude to elections, they manifest the difference in approaches as to the attitude to the whole totality of social and political problems among men and women. Historical, economic, social, political, ideological factors, separated at the analysis, are more or less manifested in gender stereotypes that function in the society, that describe and legitimize men's and women's status in the society, their attitude to different social phenomena that results in the necessity to take them into account obligatorily at organizing elections.
\end{abstract}

Keywords: gender gap, motivation of electoral behavior, electoral decisions, influence factors on gender orientation.

\section{Introduction}

The analysis of the electoral behavior of men and women in democratic countries in whole $[1,2]$, especially, less in Ukraine [3, 4] testifies to the presence of a certain problematic situation in this sphere. Especially, the grounded studies of problems of gender differences in the electoral choice, realized by the American scientists Ronald Inglehart and Pippa Norris, must be noted: the analysis is based on monitoring data of the World Values Survey (WVS), conducted in more than 60 countries of the world for fifteen years in three stages (from the beginning of 80 -ies to the middle 90-ies) [5]. Differences in the electoral behavior of men and women, who are the subject of the studies, are especially brightly manifested in the American society [6, 7]. The work by Susan Howell and Christine Day [8], that separates such factors of gender differences in the political attitude as social roles by gender, main differences of cost, socio-economic status and woman's autonomy at explaining gender gaps.

The situation, formed in Ukraine, is analogous to the one, typical for many democratic countries as to the difference in the electoral behavior of men and women that is a bright manifestation of the so-called gender gap [9, 10]. From one point of view, in the final result, as it is testified by the research results, the general indices of both electoral activity and electoral preferences (that is voting for certain parties or candidates) of men and women essentially differ in certain countries, and in certain ones - practically coincide that, from our point of view, in the first turn testifies to the "action" of general regularities of mass consciousness and mass behavior of the population, electors.

From the other side, deeper studies and analysis of gender problems indicate the presence of essential discrepancies in electoral settings, motivation of the behavior of men and women at elections. Thus, the English researcher Rosy Campbell characterizes such situation and notes that 
"the gender gap in voting at elections can be manifested in two directions. It can be manifested as a choice, whom to give the own voice, or as a motivation gender gap in the electoral choice, where men and women vote for the same party because of different causes" [11, p. 28]. The gender gap that takes place not only in the electoral or political behavior of men and women testifies to the general situation of gender differences in the status and behavior of people of the different genders in any society.

It is clear, that revelation and presence of this problem (we talk about the difference of final results and motives of such voting) have not only the essential scientific interest, but also practical importance for politologists, sociologists, political technologists and politicians that organize and conduct electoral campaigns. Unfortunately, there is no deep analysis of this problem in Ukrainian sociology for today. There are only several assumptions and analysis of certain factors that influence the electoral behavior of men and women. As to the full list of such factors that determine the electoral behavior of electors of different gender or at least influence it seriously is absent for today.

\section{Aim of research}

Determination and analysis of main factors that influence gender orientations of electors in the electoral space and motivation of making electoral decisions by them.

\section{Materials and Methods}

Starting the analysis of such complicated and insufficiently studied problem, it must be noted, that at the relative majority of women in the Ukrainian electorate, only few women are present in elected bodies, especially, central ones. Thus, in Ukraine, already at independence they didn't exceed $12 \%$ (in Verhovna Rada of VIII convocation they occupy $11,1 \%$ of the total composition, and mean international index - $22 \%$ ), and in strictures of local self-government women's representation is $10 \%$ - in regional councils, $23 \%$ - district, $14 \%$ - municipal, rural $-43 \%$, rural $-51 \%$ [12].

Let's try in the first turn to give a list of main factors that really differently influence the electoral behavior of men and women. The list, presented below, may be not exhausting, but it characterizes, from our point of view, the main groups of such factors, namely:

- historical;

- ideological;

- economic;

- social;

- political;

- gender sensitivity of legislation; - cognitive-propagandist; - especially gender that is stereotype ones.

3. 1. Historical factors that influence gender orientations of electors in the electoral space

One of such factors, by the way not often considered, is historical one. The question is that women gained the right for participation in elections much later than men in different countries. How does it influence (can it influence) the specificity of the electoral behavior? For example, it seems that during a century, passed from gaining this right by Ukrainian women, the gap between the electoral activity and preferences practically disappeared (we talk about correspondent ones as to men and women). But the real electoral practice testifies that a certain "political marginality" of the female electorate still take place.

It is explained by the fact that the policy as a sphere of social reality still alien for most women, far from close living strategies. That is why the political and electoral behavior of women is very often dictated by conformism, lack of desire to think about what happens beyond routine life. It, by the way, causes manifestations of marginality that is penetration of elements of patriarchal culture into the modern democratic civic one. Such culture dominated earlier and was reduced, as it was repeatedly noted, to the fact that even today most women in Ukraine rely at solving their 
problem, including routine ones, on the state, leaders of enterprises, that they work at, and other "sponsors", but not on own forces, efforts.

\section{2. Ideological factors that influence gender orientations of electors in the electoral space}

The ideological factor, being very close to historical one, determines the specificity of electoral behavior of women throughout the world in many aspects that is also proved by the studies, conducted in the USA and European countries; its influence is very visible also in Ukraine. It must be noted, that this factor is in general very closely connected with economic and social ones (see farther).

What is the question? Studies, conducted in Ukraine and abroad, constantly fix a tendency that the female electorate treats positively (more positively than the male one) politicians and political parties, whose programs are in the first turn oriented on social expenditures. Just for that the following "ideological" directions of the female electorate are fixed.

At-first, women-electors vote more often than men for "left" parties and politicians, today - for ones of the social-democratic direction. Just programs of such direction contain socially grounded approaches to life organization (especially, in countries of the Central and Eastern Europe), where wealthy people are heavily taxed, and poor ones gain the essential social support. In addition it must be noted, that such socio-democratic parties often pay attention to the "female agenda", help women to enter civic life, to make the politic career more actively.

At-second, it is noted everywhere, that women more often than men vote for conservative parties that have rather stable programs and propagate family values as opposite to some modern parties that propagate radicalism (especially, nationalistic ones and some others) that are hardly understood or supported by women, because of merely gender "arguments". It is interesting that in Ukraine just this "conservatism" of the female electorate motivate women to elect parties in power and politicians that have already progressed in the society and function in the political sphere for a long time.

3. 3. Economic factors that influence gender orientations of electors in the electoral space

As to economic factors that influence the motivation of the electoral behavior of the female electorate, they are hardly worth being analyzed specially. We have already talk above about the fact that women most often support just politicians and parties, whose activity is directed on realizing, in the first turn, programs of socially oriented expenditures, support of different social programs.

Thus, the American specialists Jeff Manza and Klem Brooks state that the gender gap in the president elections of the USA is based on activation of women's participation in paid work. Activation of participation grounds women's interest for expenditures of services of social care that orient women to give their voice for the political force of democratic direction more often, comparing with men. Manza and Brooks indicate that women more often than men rely on the state sector of working places, social services, connected with children (it especially concerns lonely mothers, whose possibilities for earnings are limited by existent circumstances). That is why among two main parties the Democratic one is more oriented on realization of socially oriented policy in the United States [13].

In this connection, from our point of view, it would be very interesting to make a special study, directed on determining the attitude of men and women in Ukraine to socio-economic reforms, realized today.

\section{4. Social factors that influence gender orientations of electors in the electoral space}

Social factors, social motivation of the electoral behavior of the gender groups is undoubtedly determined, in the first turn, by the fact that women and men are integrated in different spheres of social life with different intensity. Such case that men worry more about problems of business, management, policy itself, undoubtedly determines their politic and electoral activity to the great extent. 
At the same time (that is testified by the modern experience of Northern European countries) women's positions in the political sphere are strengthening more and more. And the question is that today in such European countries including Ukraine most women (they form the most part of the electorate in these countries) are better educated, sufficiently socially (unfortunately not politically) active, rather adapted to the modern conditions of social life.

That is, the problem is that these qualities of the female electorate must be used not only at conducting electoral campaigns. But first of all, at realizing the permanent political work. At second, they must be taken into account in the process of real election of women in state and regional power bodies. In such a way as it has been done for today in a series of Scandinavian countries. Unfortunately, it is very hard to be realized in Ukraine because of diverse causes, one of which - the existent electoral system, which improvement is permanently postponed. Today at forming electoral party lists, women most often enter them on so-called "impassible" places. As to their competition with men within the majority system (or its part in the mixed one), women's victories are hardly complicated by a series of causes, including absence of necessary essential material and financial resources.

3. 5. Political factors that influence gender orientations of electors in the electoral space

The next important factor that determines the electoral motivation of men and women may be called political. From our point of view, its effect is determined, in the first turn, by two following moments. At first, the level of general political competence of electors of the different genders. From our point of view, this problem doesn't need the detail elucidation, because it is rather obvious. The level of such competence in women is much lower than in men, despite the level of their social activity.

During the whole history of independent Ukraine there have been always observed gender gaps (differences between men and women) in the interest to policy and erudition as to political events and phenomena, level of political competence: women have been less interested in policy and less ready to discuss problems that needed a certain erudition in the political sphere. Such gaps varied within 2-5\% [17]. Thus, according to the data of the research, conducted by an order of DPUNO in 2016 (national representative study, 2,000 respondents), despite the general high level of involvement in political life after the Dignity Revolution, there are fixed gender gaps in the interest to news - at the level of $2 \%$ (among men 89,8\% are interested, among women - 87,6 \%), to news of neighboring countries - at the level of $3 \%$ (among men $82,4 \%$ are interested, among women $-79,1 \%$ ), to news of European countries - at the level of $5 \%$ (among men 78,1\% are interested, among women $-72,8 \%$ ). The essential interest of women to what happens in Ukraine is rather explained, if to take into account that women may feel the dependence of their private life on what happens in the country.

The researcher of gender gaps noted the less interest and erudition of women in the political sphere comparing with men, feeling of less effectiveness from their participation and realization of participation in policy mainly by voting [15]. M. Karpini and S. Keeter state that political awareness increases coordination between values of voting persons and just the choice, whom to give their voice: this connection between values and political choice is stronger at more awareness about political problems, in addition more informed electors have more stable and coordinated political position. Women are essentially less informed about political phenomena: the gender gap varies within 2-20 points. It must be noted, that changes of the socio-economic and political status of women essentially influences their interest (bias and awareness) in policy. The authors consider the main factors of the low level of political awareness as women's orientation on the private sphere (home economy and children) as opposite to men that influences the lower education level, slow career growth.

The studies of manifestations of gender gaps note that differences in political views of men and women act as the main explanation of gender differences in the electoral behavior [16]. Men are more conservative than women in a series of important political spheres and these differences in views have behavior results. The studies also fix that sometimes men and women give different priority levels in certain political problems; thus, changes in the relative importance of a problem can increase or decrease a size of the gender gap. 
In this aspect the conclusion, made by E. Kochkina, who took into account studies of other Russian sociologists, on the analysis of electoral problems in Russia [17], when the probability of the victory of the actual president was practically undoubted, is rather interesting. They noted that under such conditions the level of men's electoral activity was very low. It is understood, that just the high level of political competence, understanding of the situation at the elections, lack of desire to waste own efforts influenced formation of their absenteist orientations at the elections.

At first, the important factor that determines women's electoral activity as opposite to men's one, is a level of their participation in the activity of political parties, political and civic organizations, membership in political clubs, associations and so on. Unfortunately, it is very difficult to give necessary examples because of the absence of data of correspondent studies, but the fact is that the level of such participation of women is essentially lower than in men, especially on leading positions in Ukraine and in some other post-Soviet countries.

At the same time it doesn't mean that the level of women's participation in elections, electoral campaigns, voting is always lower comparing the men's one [18; 19]. Different studies (unfortunately, even exit-poles don't give exhaustive and reliable information that allows to compare levels of the real political activity of men and women) testify to the fact that women's activity in the electoral aspect is not inferior, but even exceed men's one [20]. But their general lower political involvement and competence often result in the fact, that women's voting for some politician or political party it is not an indicator of their political choice, but is rather traditional practice of "coming" at voting stations and manifestation of the "responsible attitude" to the participation in elections.

\section{6. The influence of gender sensitivity of legislation on gender orientations of electors in the electoral space}

The important factor that conditions the women's electoral behavior and partially relates to the political one is the gender sensitivity of legislation existing in different European countries. It just influences women's electoral activity and generally political one. We can give many examples in this aspect that testify to the fact that the special/legislative stimulation of such activity gives very important results. Let's give only one. As it is testified by the European practice the presence of gender quoting in laws that function in one or another country, from one point of view, essentially intensifies women's activity in their desire to be elected for "winning" different electoral posts and actively compete with candidates-men.

From the other side, it increases the electoral activity of women-electors, because they get a real possibility to manifest so-called "gender closeness" that is to vote for a representative of the own gender. This approach is actively used by women in different European countries for today that allowed to intensify the women's representation level in power bodies essentially. Unfortunately, such principle of gender closeness is used very weakly in Ukraine (one of author's articles deals with it). The principle of gender sensitivity of legislation was introduced at the last elections to the bodies of local self-government in Ukraine that is $30 \%$ gender quota was an obligatory norm at forming lists of candidates of political parties and blocks (The Law of Ukraine "On local elections" in article 4 «Equal suffrage" of 14 July of 2015 states: "All candidates... have equal rights and possibilities for participating in the electoral process of correspondent local elections. Representation of persons of one gender in electoral lists of candidates to local councils in multicandidate constituencies must be no less than $30 \%$ of the total number of candidates in an electoral list"'). Unfortunately, this quota functions in Ukraine only at nomination of candidates in multicandidate constituencies, so it doesn't influence real results of elections, so it cannot be fully realized, because it depends on the elector's behavior in the voting process. But this is another problem, not considered in this article.

\section{7. Cognitive-propagandist factors that influence gender orientations of electors in} the electoral space

The next group of factors that actively influence the women's electoral behavior we call cognitive-propagandist. This name is possibly unusual and insufficiently grounded in the scientific aspect, but the essence of this group of factors and mechanisms of their influence on the electoral 
behavior is rather clear. We talk about two main, rather grounded aspects of the political informational influence on women and men.

On one side, women are often less informed in political problems than men. It's not because they are not able to perceive and "process" correspondent information rather accurately. The problem is in the fact, as it has been already noted above, that policy remains for most women a sphere rather far from their living interests, so they unconsciously stand aside from it. Really, women are most often interested in political problems and address to political information at electoral campaigns. That is why they find themselves deeply aware in correspondent problems that is often and not fairly used by politicians and political technologists in the process of "electoral processing" of the female electorate.

From the other side, as it is also testified by the results of sociological and psychological studies and electoral practice, just women are more actively and essentially influenced by political propaganda. Especially, by its manipulating component. The female share of the electorate really has noticeably more impressionability as to the agitation propagandist influence on them by mass media, political advertisement, ideas of other people. Moreover, by not only ones of the close environment, but also ones of diverse activists (that are numerous in today Ukraine) and propagandists. Because women's susceptibility and emotionality is more comparing with men's ones, women can give in to both hidden influence of manipulative technologies and direct advertisement.

\section{8. Gender (stereotype) factors that influence gender orientations of electors in the electoral space}

But despite the presence of the essential number of the aforesaid factors that influence gender orientations of electors in the electoral space, motivation of making their electoral decisions, the key ones, especially we talk about the influence on the female electorate, are merely gender, understood as the influence of gender stereotypes that really occupy the important place in Ukrainian electoral processes and actively function in the electoral space on the female electorate. As it was noted by S. Oksamytna, "the analysis of results of general national interrogations testifies to the domination of a series of gender stereotypes in mass consciousness that correspond to the patriarchal ideology and practice of everyday life. It concerns ideas of the role and destination of women in the society, possibilities of working and career realization, participation in political activity and so on" [20, p.136]. Just gender stereotypes of members of the society that help to assess and explain internal settings about places of men and women in the society about their functions and main social, economic, political and other tasks, essentially (maybe mainly - it needs the additional deep sociologic study) determine the motivation of making electoral decisions. Moreover, by all social members: men and women.

Just the influence of such gender electoral stereotypes determines different aspects of the electoral behavior of the female electorate. Thus, if to turn to the problem of gender closeness, mentioned above, the results of the special empirical social research, conducted by the author, testify that only $21,7 \%$ of interrogated women think that women-electors more often vote for women-candidates in elected bodies. At that, in first, 36,8 \% of interrogated men think than women more often vote for women. And at second Ukrainian women fully understand the fact that just women, elected in elected bodies, realize tasks and solve problems that interest the population in whole and especially women. Namely, problems of education, medicine, rise of salaries and pensions, environment protection and so on.

The list of the above analyzed factors influence gender orientations of electors at making their electoral decisions, obviously may be added. Besides the aforesaid ones that belong to the series of general socio-political, socio-demographic and other, the women's electoral behavior is undoubtedly influenced by regional factors, ones, connected with election types and their organization level, use of different strategies of organizing voting campaigns and so on.

Thus, the electoral practice of modern Ukraine testifies that at elections in rural, district and municipal councils women vote for women very often and intensively (these councils contain much more women than, for example, Verhovna Rada, - proportionally), taking into account their possibilities to influence solving socio-economic, ecological and some other problems at the local level. That is why, according to the results of local elections, conducted in Ukraine in 2015, such local elected bodies contain really many women, sometimes practically the same number as men. 
The more essential electoral activity of women is also present, for example, in a case, where the strategy of dominating stereotype is used in organizing an electoral campaign. It is stated that a candidate, offered for voting is "the most honest", "most just", "most disinterested", "most generous", active fighter against corruption, or can essentially improve the population's living standards due to own income, to repair roads and so on.

\section{Results of research}

The main factors, separated in the research, differently influence the electoral behavior of men and women: historical, ideological, economic, social, political, cognitive-propagandist, stereotype. Moreover, all separated factors, excluding the last one - gender - are more or less manifested in gender stereotypes that function in the society.

According to their nature, gender stereotypes as a sort of social ones manifest, legitimize the existent gender asymmetry in the society. In general social stereotypes ground the human behavior in any society. Walter Lyppman noted that "The thinnest and most spread influence mechanisms are ones that create and repeat the repertoire of stereotypes. We hear about the world before seeing it, we gain ideas about most things before directly meeting them" [21, p. 108].

The real influence on the electoral behavior in this aspect is technologically realized by gender stereotypes as to elections, their organization, participation in them. Gender electoral stereotypes - are stable generalizing ideas of women and men about their behavior in the process of democratic elections, including in the first turn voting for political parties and candidates for elected posts, rooted in mass consciousness.

The totality of the same historical, ideological, economic, social, political and other mechanisms (factors) influence men and women differently. Just this fact causes (may cause) their different attitudes to the participation in elections and specific electoral preferences. From our point of view, the main factor or mechanism that conditions gender specificity of the electoral behavior is the presence of specific stereotypes and their real action in the electoral process. They are at first electoral, at second - gender. In other words for determining the specificity of the electoral behavior of, for example, women, it is necessary to determine gender stereotypes as to social phenomena, political events and political parties, historically formed ideas about their behavior at elections that dominate among them and so condition how they act at voting stations.

\section{Conclusions}

The conducted analysis of problems of the gender influence on making electoral decisions by representatives of the different genders, specificity of their electoral activity, allows to make the following conclusions:

1. The electoral behavior of men and women, their participation in elections and electoral preferences have essential, permanently reproduced gender gaps in electoral activity and choice of a person for voting, despite external likeness that sometimes take place.

2. There was determined, that such differences are influenced by the series of factors that determine the gender orientations of electors in the electoral space. Among them historical, ideological, economic, social, political, cognitive-propagandist, stereotype (gender), gender sensitivity of electoral legislation.

3. Together with the series of other partial factors, especially such as regional, types and levels of electoral campaigns, use of different strategies at their organization and so on these factors determine the real motivation of gender electoral behavior.

4. Such separated factors as historical, economic, social, political, ideological factors, separated at the analysis, are more or less manifested in gender stereotypes that function in the society and describe and legitimize men's and women's status in the society, their attitude to different social phenomena.

\section{References}

[1] Giger, N. (2009). Towards a modern gender gap in Europe?: A comparative analysis of voting behavior in 12 countries. The Social Science Journal, 46 (3), 474-492. doi: 10.1016/j.soscij.2009.03.002 
[2] Quick, T. (2014). The Modern Gender Gap in Partisanship and Ideology: a Cross-National Analysis. Orlando, 69.

[3] Mishchenko, M. (2007). Elektorat parlamentskikh viboriv u demografichnikh vimirakh. Natcionalnii ekzit-pol: pozachergovi parlamentski vibory'2007. Kyiv: Tcentr “Demokratichni initciativi”, 49-85.

[4] Nuzhna, Yu. S. (2013). Henderni ta vikovi osoblyvosti elektoralnoi povedinky u velykomu misti (na prykladi vyboriv do Verkhovnoi Rady Ukrainy 28 zhovtnia 2012 r. u m. Luhansku). Visnyk Luhanskoho natsionalnoho universytetu imeni Tarasa Shevchenka. Sotsiolohichni Nauky, (11 (1)), 113-126.

[5] Inglehart, R., Norris, P. (2000). The Developmental Theory of the Gender Gap: Women's and Men's Voting Behavior in Global Perspective. International Political Science Review, 21 (4), 441-463. doi: 10.1177/0192512100214007

[6] Box-Steffensmeier, J. M., De Boef, S., Lin, T.-M. (2004). The Dynamics of the Partisan Gender Gap. American Political Science Review, 98 (3), 515-528. doi: 10.1017/s0003055404001315

[7] Carroll, S. J.; Carroll, S. J., Fox, R. L. (Eds.) (2014). Voting Choices: How and Why the Gender Gap. Gender and Elections: Shaping the Future of American Politics. New York: Cambridge University Press, 119-145. doi: 10.1017/cbo9781139199216.005

[8] Howell, S. E., Day, C. L. (2000). Complexities of the Gender Gap. The Journal of Politics, 62 (3), 858-874. doi: 10.1111/0022-3816.00036

[9] Prokopchuk, I. I. (2012). Elektoralna povedinka: hendernyi aspekt. Nova paradyhma, 112, 165174. Available at: http://nbuv.gov.ua/UJRN/Nopa_2012_112_21

[10] Strelnyk, O. (2005). Henderna nerivnist: teoretyko-metodolohichni pidkhody do interpretatsii. Sotsiolohiia: teoriia, metody, marketynh, 4, 147-154.

[11] Campbell, R. (2004). Gender, ideology and issue preference: Is there such a thing as a political women's interest in Britain? The British Journal of Politics \& International Relations, 6, 20-44. doi: 10.1111/j.1467-856x.2004.00125.x

[12] Za predstavnytstvom zhinok u parlamenti Ukraina posila 107 mistse u sviti (2015). Available at: https:/time-ua.com/novini/suspilstvo/15811-za-predstavnictvom-jnok-u-parlament-ukrana-posla107-msce-u-svt

[13] Manza, J., Brooks, C. (1998). The Gender Gap in U.S. Presidential Elections: When? Why? Implications? American Journal of Sociology, 103 (5), 1235-1266. doi: 10.1086/231352

[14] Aleksieieva, H., Balakirieva, O., Bondarovska, V. et. al. (2003). Hendernyi parytet v umovakh rozbudovy suchasnoho ukrainskoho suspilstva. Kyiv: Ukrainskyi instytut sotsialnykh doslidzhen, 130.

[15] Carpini, M., Keeter, S. (1992). The gender gap in political knowledge. The public perspective, $3(5), 23-26$.

[16] Chaney, C. K., Alvarez, R. M., Nagler, J. (1998). Explaining the Gender Gap in U.S. Presidential Elections, 1980-1992. Political Research Quarterly, 51 (2), 311-339. doi: 10.1177/106591299805100202

[17] Kochkina, E. V. (2006). Rossiyskiy elektorat: demograficheskiy razryv kak politicheskiy resurs gendernoy segmentatsii. Zhenshhina v rossiyskom obshhestve, 3, 47-60. Available at: https://womaninrussiansociety.ru/article/kochkina-e-v-rossijskij-elektorat-demograficheskij-razryv-kak-politicheskij-resurs-gendernoj-segmentacii-str-47-60/

[18] Prokopchuk, I. I. (2012). Elektoralna povedinka: hendernyi aspect. Nova paradyhma, 112, 165174. Available at: http://nbuv.gov.ua/UJRN/Nopa_2012_112_21

[19] Dziuba, N. (2008). Vplyv henderu na spryiniattia elektoralnoho prostoru. Sotsialni vymiry suspilstva, 11, 191-201.

[20] Oksamytna, S. (2004). Henderni vidnosyny kriz pryzmu hromadskoi dumky v Ukraini i sviti. Henderna perspektyva. Kyiv: Fakt, 135-147.

[21] Lyppman, U. (2004). Obshchestvennoe mnenye. Moscow, 384. 